\title{
Inventory and ethnobotanical assessment of plant species in Lagos State University, Ojo campus, Lagos, Nigeria
}

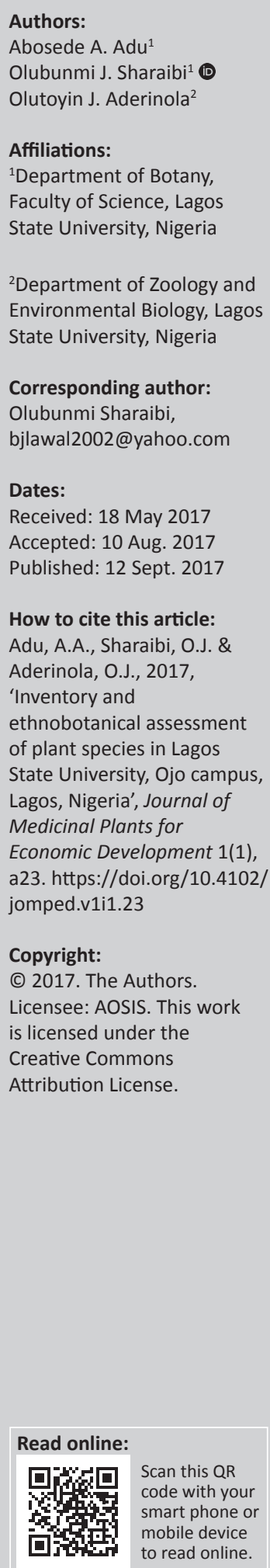

\section{Copyright:}

(c) 2017. The Authors. Licensee: AOSIS. This work is licensed under the Creative Commons Attribution License.

\begin{abstract}
Inventory and ethnobotanical assessment of plant species growing on Lagos State University (LASU) Ojo main campus, Lagos State, Nigeria, were carried out. The aim was to document the vegetation composition and ethnobotanical uses of plants in the study area with a view to developing strategies for their conservation. Plant species with their frequency of occurrence were compiled and their representatives were collected for proper identification. Ethnobotanical assessment was carried out through oral interviews of herbalists, herb sellers and others with experience in traditional medicine. A total of 35 plant species belonging to 25 families were recorded from the survey. Poaceae has the highest number of species; Anacardiaceae, Asteraceae, Asparagaceae, Combretaceae, Euphorbiaceae, Malvaceae and Moraceae were all represented with two species each while the remaining 17 families were represented with one species each. Murraya paniculata recorded the highest frequency of occurrence within the study area with 165 individual plants followed by Ficus benjamina with 134 plants, then Ixora coccinea with 121 plants and Terminalia ivorensis with 103 plants. Anarcardium occidentale, Araucaria heterophylla and Ficus carica recorded the lowest frequency of occurrence with two plants each. The trees were the dominant plant habit ( $46 \%$ ) followed by the shrubs (23\%), grasses $(17 \%)$ and herbs $(14 \%)$. The plant species identified are of significant ethnobotanical uses ranging from food to medicine and ornamental. Effective conservation strategies for these plants include enacting laws against indiscriminate tree cutting, encouraging afforestation, proper maintenance of the parks and gardens and establishment of medicinal plant farms.
\end{abstract}

\section{Introduction}

Taxonomic surveys have been helpful in documenting the species that had one time or an other existed in different locations within the country (Anoliefo et al. 2006; Soladoye et al. 2005, 2013) and the value of any biodiversity analysis and the adequacy of conservation measures depend on the quality of basic data, as put by Valdecasas and Camacho (2003). Similar studies have also been used to document medicinal plants reported to be valuable in the traditional management of ailments in Nigeria and other West African countries (Asase et al. 2005; Bhat, Etejere \& Oladipo 1990; Soladoye et al. 2014). Plants and animals are very important to human survival and thus need to be studied and taken adequate care of, because of their importance in maintaining the ecological balance of our region. Ogie-Odia et al. (2010) reported that forest diversity is increasingly threatened as a result of deforestation, fragmentation, climate change and other stressors. The rich flora diversity is a major source of raw plant materials that enable sustainability in the human communities now and in the future. In addition, research has equally shown that plant diversity could affect food web connectivity in a variety of ways ( $\mathrm{O}^{\prime}$ Gorman \& Emmerson 2009). Higher plant diversity increases plant productivity and predator abundance (Haddad et al. 2009), which increases the amount of energy transfer among interacting species and thus increases food web connectivity. Consequently, such a measure should begin from the immediate environment and, hence, from our campus flora and fauna. Plants and animals are sources of food, shelter and clothing. A healthy ecosystem is built when it is maintained in a sustainable manner. Hence, this study was designed to establish the flora profile as well as to document the ethnobotanical values of plant species growing on Lagos State University main campus, Ojo, Lagos State, Nigeria with a view to develop strategies for their conservation.

Lagos State University, Ojo, was established in the year 1983 by then governor of Lagos State Mr Lateef Jakande and was located along Badagry Expressway, Ojo. In the beginning of her academic carrier, the university started with three faculties, namely Law and Humanities, Education and Science. Today, the university has 11 faculties and is to increase to more than that in the nearest future. In early 1984, the surrounding areas were highly forested and swampy and composed of varieties of different flora of trees, shrubs and grasses but today the vegetation is 
dominated by grasses and shrubs with trees sparsely distributed in the area. Currently, the flora is being deteriorated because of construction of new buildings such as new senate building, new faculty of Science building, new radio station, new auditorium, sandwich building and sport centre.

Today, the old landmass has given way to new vegetation replacing indigenous and exotic vegetation. The planting of exotic vegetation started in 1990 by the then head of the Botany Department. Not all the indigenous vegetation has the capacity of self-regeneration. Nowadays, the university campus is well rehabilitated and it is very important that the composition of the vegetation, the regeneration capacity of the vegetation and the importance of the tree species are studied.

\section{Materials and methods}

\section{Study area}

This study was conducted in Lagos State University, Ojo main campus, Lagos State, south-western Nigeria. It lies on latitude $6.26^{\circ} \mathrm{N} 3.11^{\circ} \mathrm{S}$ and longitude $6.467^{\circ} \mathrm{W} 3.183^{\circ} \mathrm{E}$ (Figure 1). The area is characterised by various floras such as grasses, shrubs and trees. Trees are relatively dispersed and the vegetation is dominated by grasses and shrubs compared to trees. The terrain is flat and more than half is dominated by buildings. The vegetation is largely affected by human activities. The study area was divided into eight sampling plots as follows:

1. Faculty of Management Sciences and Iyana-Ipaja gate.

2. Faculty of Education, Faculty of Social Science and Faculty of Transport.

3. Faculty of Science.

4. Sports Centre and Student Affairs Division.

5. Master of Business Administrative and Information Communication and Technology (ICT) area.

6. Faculty of Law.

7. Faculty of Art.

8. Central administrative blocks and Iyana-Iba gate.

\section{Collection and identification of plant species}

Field collection and identification of plant species occurring within the university community was conducted between June 2015 and November 2016. The occurrences of plant specimens in each zone were recorded. The collected plant species were identified by plant taxonomists in the Department

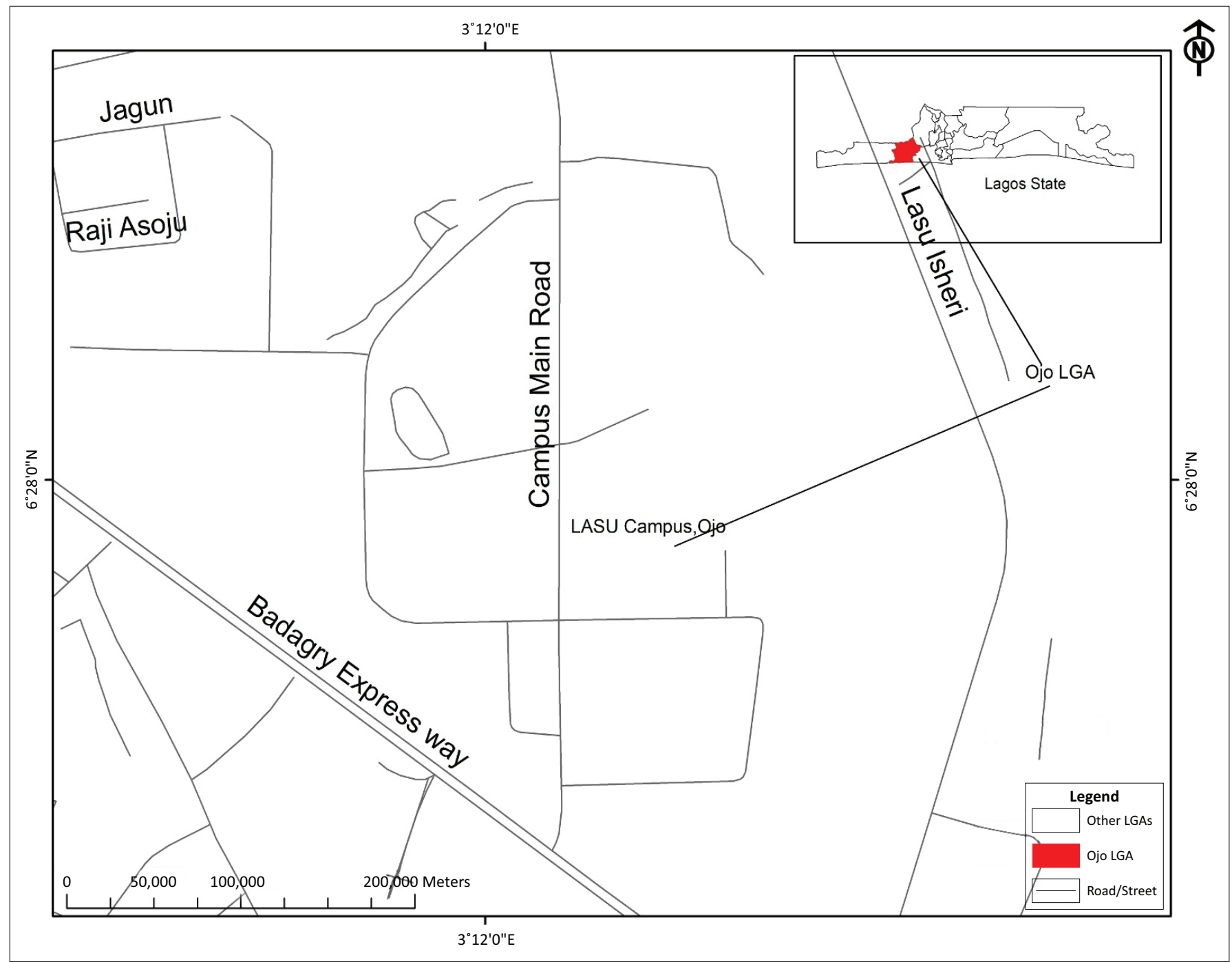

FIGURE 1: Map of Ojo Local Government Area (LGA) of Lagos State showing the location of the study area. 
of Botany, Lagos State University. Correct names of the identified species follow International Plant Name Index (IPNI). A comprehensive list of species was thereafter carefully documented, along with their families, habits and local names by which they are known within the study area.

\section{Ethnobotanical assessment}

Ethnobotanical information about the identified plant species was obtained through oral interviews. The interviews were conducted randomly with a total of 60 local respondents including herb sellers, herbalists, elderly people and others with knowledge of herbal medicine (Table 1). The

TABLE 1: Distribution of local informants in accordance with their age groups.

\begin{tabular}{lccccc}
\hline \multirow{2}{*}{ Age groups } & \multicolumn{5}{c}{ Categories of informants } \\
\cline { 2 - 6 } & Herb sellers & Herbalists & Elderly people & Others & Total \\
\hline $31-40$ & 5 & - & - & 1 & 6 \\
$41-50$ & 10 & 3 & - & 2 & 15 \\
$51-60$ & 5 & 2 & 2 & 2 & 11 \\
$61-70$ & 6 & 2 & 4 & 1 & 13 \\
71 and above & 5 & 3 & 6 & 1 & 15 \\
\hline Total & $\mathbf{3 1}$ & $\mathbf{1 0}$ & $\mathbf{1 2}$ & $\mathbf{7}$ & $\mathbf{6 0}$ \\
\hline
\end{tabular}

consent of all the respondents was sought before the interviews. The interviews were held in local language (Yoruba); hence, there was no need for interpreters and this allowed accurate data recording. The information collected included the local names, ethnobotanical uses, the parts used, modes of preparation and administration of the identified plants.

\section{Results}

The profile of the local respondents interviewed for the ethnobotanical uses of the identified plant species on Lagos State University main campus is shown in Table 1.

Thirty-five plant species belonging to 25 families were found within the Lagos State University campus as shown in Table 2. Family Poaceae had the highest number of species (16\%) followed by families Anarcardiaceae, Asparagaceae, Asteraceae, Combretaceae, Euphorbicaeae, Malvaceae and Moraceae with two species each $(8 \%)$ while the remaining families were represented with one species each $(4 \%)$ as represented in Table 3. Murraya paniculata recorded the highest frequency of occurrence within the study area with 165

TABLE 2: Distribution of plant species in Lagos State University campus.

\begin{tabular}{|c|c|c|c|}
\hline Botanical name & Common name & Family & Habit \\
\hline Acalypha wilkesiana Muell Arg. & Red acalypha & Euphorbiaceae & Shrub \\
\hline Anacardium occidentale $\mathrm{L}$. & Cashew & Anacardiaceae & Tree \\
\hline Andropogon gayanus Kunth. II & Guinea grass & Poaceae & Grass \\
\hline Araucaria heterophylla (Salisb.) Franco. & Monkeytail puzzle & Araucariaceae & Tree \\
\hline $\begin{array}{l}\text { Archontophoenix } \\
\text { cunninghamiana } \mathrm{H} \text {. Wendl. }\end{array}$ & King's palm & Arecaceae & Tree \\
\hline Axonopus compressus (Sw.) Beauv & Carpet grass & Poaceae & Grass \\
\hline Azadiractha indica A. Juss & Neem plant & Meliaceae & Tree \\
\hline Carica papaya L. & Pawpaw tree & Caricaceae & Tree \\
\hline Casuarina equistefolia L. & Scotch pine & Casuarinaceae & Tree \\
\hline Canna indica $\mathrm{L}$. & Canna lily & Cannaceae & Herb \\
\hline Codiaeum variegatum (L.) Blume & Croton & Euphorbiaceae & Shrub \\
\hline Cordyline fruticosa (L.) A. Chev & Cordyline & Asparagaceae & Herb \\
\hline Cycas revoluta Thunb. & Cycads & Cycadaceae & Shrub \\
\hline Delonix regia (Bojer ex Hook.) Raf. & Flame of the forest & Fabaceae & Tree \\
\hline Dieffenbachia seguine (Jacq.) Schott. & Dumbcane plant & Araceae & Herb \\
\hline Eucalyptus globulus Labill. & Blue gum & Myrtaceae & Tree \\
\hline Ficus benjamina $\mathrm{L}$. & Weeping fig & Moraceae & Tree \\
\hline Ficus carica L. & Fig tree & Moraceae & Tree \\
\hline Gmelina arborea Roxb. & Beechwood/Gmelina & Lamiaceae & Tree \\
\hline Hibiscus variegatum $\mathrm{L}$. & Variegated hibiscus & Malvaceae & Shrub \\
\hline Imperata cylindrica (L) Raeuschel. & Blady/cogon grass & Poaceae & Grass \\
\hline Ixora coccinea $\mathrm{L}$. & Wild ixora & Rubiaceae & Shrub \\
\hline Mangifera indica L. & Mango & Anacardiaceae & Tree \\
\hline Murraya paniculata (L.) Jack. & Orange jasmine & Rutaceae & Shrub \\
\hline Musa paradisiaca L. & Banana & Musaceae & Herb \\
\hline Polyalthia longifolia Thwaites & Masquerade tree & Annonaceae & Tree \\
\hline Ravenala madagariensis Sonn. & Traveller's palm & Strelitziaceae & Tree \\
\hline Rheo discolour L. B. Sm. \& H. Rob & Boat lily & Commelinaceae & Herb \\
\hline Sida acuta Burm. f. & Wire weed & Malvaceae & Grass \\
\hline Terminalia catappa L. & Indian almond & Combretaceae & Tree \\
\hline Terminalia ivorensis A. Chev & Black afara & Combretaceae & Tree \\
\hline Tithonia diversifolia (Hemsl.) A. Gray. & Mexican sunflower & Asteraceae & Grass \\
\hline Vernonia amygdalina Del. & Bitter leaf & Asteraceae & Shrub \\
\hline
\end{tabular}


TABLE 3: Species distribution within the identified families.

\begin{tabular}{ll}
\hline Families & Number of species \\
\hline Anarcardiaceae & 2 \\
Annonaceae & 1 \\
Araceae & 1 \\
Araucariaceae & 1 \\
Arecaceae & 1 \\
Asparagaceae & 2 \\
Asteraceae & 2 \\
Cannaceae & 1 \\
Caricaceae & 1 \\
Casuarinaceae & 1 \\
Commeliaceae & 1 \\
Combretaceae & 2 \\
Cycadaceae & 1 \\
Euphorbiaceae & 2 \\
Fabaceae & 1 \\
Lamiaceae & 1 \\
Malvaceae & 2 \\
Meliaceae & 1 \\
Moraceae & 2 \\
Musaceae & 1 \\
Myrtaceae & 1 \\
Poaceae & 4 \\
Rubiaceae & 1 \\
Rutaceae & 1 \\
Strelitziaceae & \\
\hline & \\
\hline
\end{tabular}

individual plants followed by Ficus benjamina with 134 plants then Ixora coccinea with 121 plants and Terminalia ivorensis with 103 plants. Anarcardium occidentale, Araucaria heterophylla and Ficus carica recorded the lowest frequency of occurrence with two plants each (Table 4 .) Trees were the dominant plant habit, comprising 16 angiosperm species (46\% of the total enumeration). This was followed by shrubs with eight species $(23 \%)$, grasses with six species $(17 \%)$ and herbs with five species (14\%) as shown in (Figure 2). The identified plant species were of significant ethnobotanical values ranging from food to medicinal and ornamental as represented in Table 5.

\section{Discussion}

This study was able to compile the flora diversity on Lagos State University campus. In the various sampling plots, plant species varies in diversity and occurrence; T. ivorensis and Ficus bejamina were well dominated in all the plots. This work is related to the flora in Bowen University Iwo, Osun State, where research was conducted on the angiosperm diversity, (Anoliefo et al. 2006; Soladoye et al. 2005). Similar survey was conducted which was based on some medicinal plant species of Southwestern University Nigeria campus, Ogun State, Nigeria; a total of 90 plant species belonging to 48 families and 85 genera were recorded in which Euphorbiaceae has the highest number of species (8) followed closely by Asteraceae (6) and Papilionaceae (5 species) (Soladoye et al. 2013). Similar survey was conducted on the endangered tree species in Cross River State and its environs; 85 endangered tree species were reported (Oguntala et al. 1996).

Plants found in the study area are of significant economic importance, ranging from medicinal to food and ornamental.
TABLE 4: Frequency of occurrence of plant species on Lagos State University campus.

\begin{tabular}{|c|c|c|}
\hline Name of plant & Number & Percentage \\
\hline Murraya paniculata & 165 & 12.20 \\
\hline Ficus benjamina & 134 & 9.90 \\
\hline Ixora coccinea & 121 & 8.94 \\
\hline Terminalia ivorensis & 103 & 7.61 \\
\hline Tithonia diversifolia & 90 & 6.65 \\
\hline Acalypha wilkesiana & 85 & 6.28 \\
\hline Cymbopogon citratus & 70 & 5.17 \\
\hline Axonopus compressus & 70 & 5.17 \\
\hline Polyalthia longifolia & 58 & 4.29 \\
\hline Azadiratcha indica & 54 & 3.99 \\
\hline Sida acuta & 50 & 3.70 \\
\hline Andropogon gayanus & 50 & 3.70 \\
\hline Vernonia amygdalina & 40 & 2.96 \\
\hline Imperata cylindrical & 35 & 2.59 \\
\hline Dieffenbachia seguine & 31 & 2.29 \\
\hline Delonix regia & 30 & 2.22 \\
\hline Codiaeum variegatum & 25 & 1.85 \\
\hline Gmelina arborea & 23 & 2.11 \\
\hline Archontophoenix cumminghamiana & 18 & 1.33 \\
\hline Cordyline fruticosa & 15 & 1.11 \\
\hline Sanseviera trifasciata & 15 & 1.11 \\
\hline Hibiscus variegatum & 10 & 1.70 \\
\hline Rheo diversicolor & 10 & 0.74 \\
\hline Canna indica & 9 & 0.67 \\
\hline Terminalia catapa & 8 & 0.59 \\
\hline Casuarina equisetifolia & 6 & 0.44 \\
\hline Cycas revolute & 6 & 0.44 \\
\hline Mangifera indica & 6 & 0.44 \\
\hline Eucalyptus globulus & 5 & 0.37 \\
\hline Musa paradisiaca & 5 & 0.37 \\
\hline Carica papaya & 3 & 0.02 \\
\hline Ravenela madagascariensis & 3 & 0.22 \\
\hline Anarcardium occidentale & 2 & 0.15 \\
\hline Araucaria heterophylla & 2 & 0.15 \\
\hline Ficus carica & 2 & 0.14 \\
\hline Total & 1353 & 100 \\
\hline
\end{tabular}

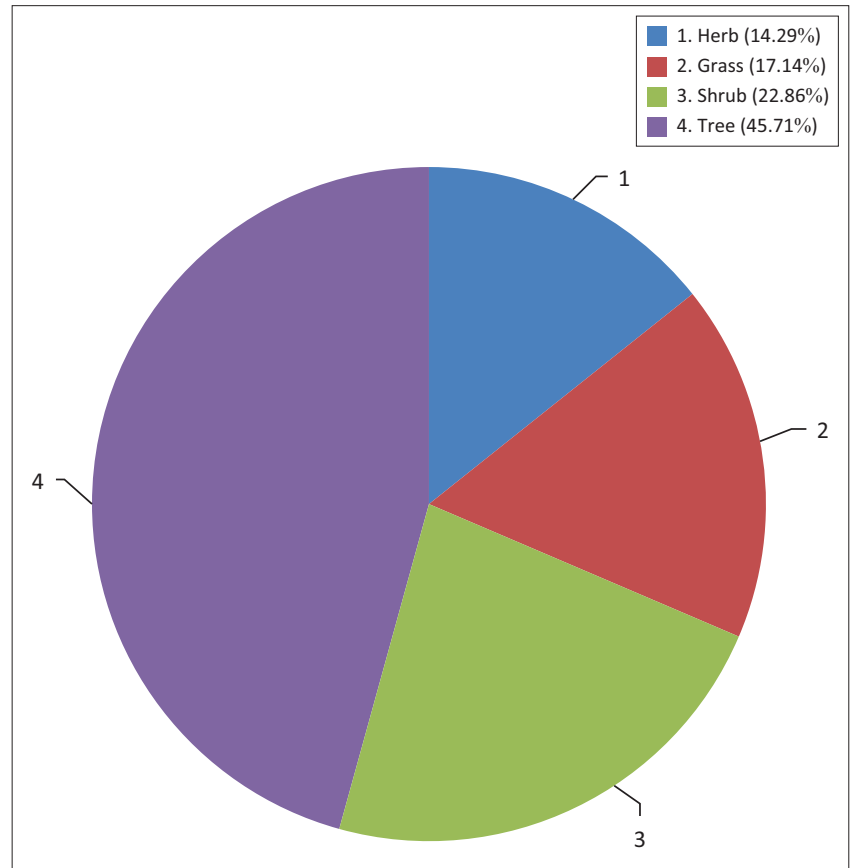

FIGURE 2: Distribution of plant habit within Lagos State University campus. 
TABLE 5: Ethnobotanical uses of identified plant species in Lagos State University campus.

\begin{tabular}{|c|c|}
\hline Botanical name & Ethno-botanical uses \\
\hline Acalypha wilkesiana & Used to treat skin irritations and diseases in children \\
\hline Anacardium occidentalis & Treatment of fever, diarrhoea, hypotension and sore throat \\
\hline Andropogon gayanus & Valuable hay and green fodder grass and also used for weaving grass mats and thatching \\
\hline Araucaria heterophylla & Ornamental \\
\hline Archontophoenix cunninghamiana & Ornamental \\
\hline Axonopus compressus & Curative herbal bath and to treat heart problems \\
\hline Carica papaya & Treatment of high blood pressure, dyspepsia, constipation, amenorrhoea, general debility, expel worms and stimulate reproductive organs \\
\hline Casuarina equistefolia & Antidiabetic, anti-hyperlipidermic and antibacterial \\
\hline Canna indica & Treatment of gonorrhoea and amenorrhoea; also considered to be demulcent, diaphoretic and diuretic \\
\hline Codiaeum variegatum & Treatment of fever, antibacterial and antiamoebic \\
\hline Cordyline fruticosa & Used to soothe sore back muscles and to aid nerve and muscle relaxation \\
\hline Cycas revoluta & Used in the treatment of cancer \\
\hline Delonix regia & Ornamental and also used in the treatment of earache, constipation and diabetes \\
\hline Dieffenbachia seguine & Ornamental \\
\hline Eucalyptus globulus & Treatment of cough, cold and catarrh \\
\hline Ficus benjamina & Treatment of wounds, bruises and rheumatic headache \\
\hline Ficus carica & Edible and also used as anti-inflammatory agent \\
\hline Gmelina arborea & Improves appetite and used for the treatment of ulcers, headache, abdominal pains and urinary tract discharge \\
\hline Hibiscus variegatum & Used as fumigants and insect repellants \\
\hline Imperata cylindrica & To treat digestive disorders and as anti-helminthic \\
\hline Ixora coccinea & Used for dysmenorrhea and skin diseases \\
\hline Mangifera indica & Treatment of malaria and fever; also used as anti-inflammatory and antimicrobial agent \\
\hline Murraya paniculata & Ornamental and also used as anti-inflammatory and anti-diarrhoea \\
\hline Musa paradisiaca & Edible and used for the treatment of gastric disorders \\
\hline Polyalthia longifolia & Ornamental and used for the treatment of fever \\
\hline Ravenala madagariensis & Ornamental \\
\hline Rheo discolour & Used for cough, colds and nose bleed \\
\hline Sida acuta & Treatment of asthma, ulcers and veneral diseases; also used as anti-helmintic \\
\hline Terminalia catappa & The fruits are edible while the leaves are used as anticancer, antidiabetic and anti-inflammatory \\
\hline Terminalia ivorensis & To treat skin diseases, inflammation and voice loss \\
\hline Tithonia diversifolia & Used for sore throat, malaria, bruises and fractures \\
\hline Vernonia amygdalina & Edible and also used medicinally to treat fever, malaria and purgative, anti-diabetic chemopreventive and immune booster \\
\hline
\end{tabular}

Similiar to the results of the ethnobotanical assessment of the identified plant species, some of the plants in the study area have been reported to have significant ethnobotanical values. Acalypha wilkesiana for skin irritations and diseases (Omage \& Azeke 2014), Azadirachta indica for malaria (Alzohairy 2016), Cycas revoluta as antimicrobial (Mathur et al. 2011), Cymbopogon citratus as anti-diarrhoeal (Shah et al. 2011), Dieffenbachia seguine as ornamental (Cuartas \& Farfan 2006), Eucalyptus globulus for cold, coughs and nasal congestion (Patil \& Nitave 2014), Gmelina arborea as laxative and anti-helminthic (Pathala, Harini \& Hedge 2015), Mangifera indica as food and antioxidant (Parvez 2016), Musa paradisiaca for diabetes (Kumar et al. 2012), M. paniculata as anti-inflammatory (Dosoky et al. 2016), Vernonia amygdalina as purgative, antioxidative and chemopreventive (Farombi \& Owoeye 2011) and so on. This justifies the importance of plant species in the maintenance of ecosystem and as a source of livelihood for man; hence, these must be conserved properly (Soladoye et al. 2015).

\section{Conclusion}

This study showed that Lagos State University is rich in plant biodiversity that are of significant ethnobotanical value; thus, the need to conserve them from further deterioration because of human activities is very paramount. From this investigation, there are many important medicinal plants found in the study area which could serve as sources of raw materials to pharmaceutical and cosmetic industries as well as other manufacturing industries in Nigeria and globally. Bio-prospecting in this area would lead to income generation for the university community. Medicinal plants identified also have marketing potentials; therefore, efforts should be geared towards creating an enabling environment for their existence and preventing overexploitation. Indigenous knowledge of these medicinal plants should also be properly preserved so that such would not be lost. Deforestation which is a major problem in the study area should be discouraged and afforestation practices encouraged in the area. Construction work and developmental projects should consider plants species found in the study area and proper analysis should be done before commencement of such projects.

\section{Acknowledgements Competing interests}

The authors declare that they have no financial or personal relationships which may have inappropriately influenced them in writing this article. 


\section{Authors' contributions}

A.A.A. was the project leader. A.A.A. conceptualised, designed and supervised the project. O.J.S. made conceptual contributions, carried out the literature search and edited the manuscript while O.J.A. carried out data acquisition and analysis as well as manuscript preparation.

\section{References}

Alzohairy, M.A., 2016, 'Therapeutic role of Azadirachta indica (Neem) and their active constituents in diseases prevention and treatment', Evidence-Based constituents in diseases prevention and treatment', Evidence-Bo
Complementary and Alternative Medicine 2016, Article ID 7382506, 1-11.

Anoliefo, G.O., Ikhajiagbe, B., Okonofhua, B.O. \& Diafe, F.V., 2006, 'Eco-taxonomic distribution of plant species around motor mechanic workshops in Asaba and Benin City, Nigeria: Identification of oil tolerant plant species', African Journal of Biotechnology 5, 1757-1762.

Asase, A., Oteng-Yeboah, A.A., Odamtten, G.T. \& Simmonds, M.S.J., 2005, 'Ethnobotanical study of some Ghanaian anti-malarial plants', Journal of Ethnopharmacology 99, 273-279. https://doi.org/10.1016/j.jep.2005.02.020

Bhat, R.B., Etejere, E.O. \& Oladipo, V.T., 1990, 'Ethnobotanical studies from Centra Nigeria', Economic Botany 44, 382-390. https://doi.org/10.1007/BF03183923

Cuartas, S. \& Farfan, J.N., 2006, 'The genetic structure of the tropical understory herb, Dieffenbachia seguine before and after forest fragmentation', Evolutionary Ecology Research 8(6), 1061-1075.

Dosoky, N.S., Satyal, P., Gautam, T.P. \& Setzer, W.N., 2016, ‘Composition and biological activities of Murraya paniculata (L.) Jack Essential Oil from Nepal', Medicines 2 , 1-10. https://doi.org/10.3390/medicines3010007

Farombi, E.O. \& Owoeye, O., 2011, 'Antioxidative and chemopreventive properties of Vernonia amygdalina and Garcinia biflavonoids', International Journal of
Environmental Research and Public Health 8, 2533-2555. https://doi.org/10.3390/ ijerph8062533

Haddad, N.M., Crutsinger, G.M., Gross, K., Haarstad, J., Knops, J.M.H. \& Tilman, D., 2009, 'Plant species loss decreases arthropod diversity and shifts trophic structure', Ecology Letters 12, 1029-1039. https://doi.org/10.1111/j.1461-0248. 2009.01356.x

Kumar, K.P., Bhowmik, D., Duraivei, S. \& Umadevi, M., 2012, 'Traditional and medicinal uses of banana', Journal of Pharmacognosy and Phytochemistry 1(3), 51-63.
Mathur, A., Mourya, M.K., Prakash, A., Swami, A. \& Singh, G.K., 2011, 'Leaves of Cycas revoluta: Potent antimicrobial and antioxidant agent', World Journal of Science and Technology 1(10), 11-20.

O'Gorman, E.J. \& Emmerson, M.C., 2009, 'Perturbations to trophic interactions and the stability of complex food webs', Proceedings of National Academy of Science 106, 13393-13398. https://doi.org/10.1073/pnas.0903682106

Ogie-Odia, E.A., Erhenhi, A.H., Ikhajiagbe, B. \& Ogbemudia, F.O., 2010, 'Survey of some indigenous plants used by the Ogba people of Oredo Local Government Area of Edo State', Journal of Research in Bioscience 6(1), 19-24.

Oguntala, A.B., Soladoye, M.O., Ugbogu, O.A. \& Fasola, T.R., 1996, 'A review of endangered tree species of Cross River State and environs', in Proceedings of the Workshop on Rain Forest of South Eastern Nigeria and South Western Cameroon, October 20-24, Calabar, Nigeria, pp. 120-125.

Omage, K. \& Azeke, A.M., 2014, 'Medicinal potential of Acalypha wilkesiana leaves', Advances in Research 2(11), 655-665. https://doi.org/10.9734/AIR/2014/9452

Parvez, G.M., 2016, 'Pharmacological activities of Mango (Mangifera indica): A review', Journal of Pharmacognosy and Phytochemistry 5(3), 01-07.

Pathala, D., Harini, A. \& Hedge, P.L., 2015, 'A review on Gambhari (Gmelina arborea Roxb)', Journal of Pharmacognosy and Phytochemistry 4(2), 127-132.

Patil, V.A. \& Nitave, S.A., 2014, 'A review on Eucalyptus globulus: A divine medicinal herb', World Journal of Pharmacy and Pharmaceutical Sciences 3(6), 559-567.

Shah, G., Shri, R., Panchal, V., Sharma, N., Singh, B. \& Mann, A.S., 2011, 'Scientific basis for the therapeutic use of Cymbopogon citratus Stapf. (Lemon grass)', Journal of Advanced Pharmaceutical Technology and Research 2(1), 3-8. https://doi.org/ 10.4103/2231-4040.79796

Soladoye, M.O., Chukwuma, E.C., Sulaiman, O.M. \& Feyisola, R.T., 2014, 'Ethnobotanical survey of plants used in the traditional treatment of female infertility in Southwestern Nigeria', Ethnobotany. Research Applications 12, 81 90. https://doi.org/10.3923/jps.2015.244.252

Soladoye, M.O., Emmanuel, C., Chukwuma, J., Fagbenro, A. \& Adelagun, E.O., 2015, 'A checklist of angiosperm diversity of Bowen University Campus, Iwo, Osun State, Nigeria', Journal of Plant Sciences 10, 244-252.

Soladoye, M.O., Ikotun, T., Chukwuma, E.C., Ariwaodo, J.O., Ibhanesebor, G.A., AgboAdediran, O.A. et al., 'Our plants, our heritage: Preliminary survey of some medicinal plant species of Southwestern University Nigeria Campus, Ogun State, Nigeria', Annuals of Biological Research 4(12), 27-34.

Soladoye, M.O., Sonibare, M.A., Nadi, A.O. \& Alabi, D.A., 2005, 'Indigenous angiosperm biodiversity of Olabisi Onabanjo University', African Journal of Biotechnology 4 554-562.

Valdecasas, A.G. \& Camacho, A.I., 2003, 'Conservation to the rescue of taxonomy', Biodiversity Conservation 12,1113-1117.https://doi.org/10.1023/A:1023082606162 